\title{
Publisher Correction: A shared Runx1-bound Zbtb16 enhancer directs innate and innate-like lymphoid lineage development
}

\author{
Ai-Ping Mao, ${ }^{1,2}$, Isabel E. Ishizuka ${ }^{1,2}$, Darshan N. Kasal1,2, Malay Mandal (10 1,3 \& Albert Bendelac ${ }^{1,2}$
}

Nature Communications 8:863 doi:10.1038/s41467-017-00882-0; Article published online 16 October 2017

In the original PDF version of this Article, which was published on 16 October 2017, the publication date was incorrectly given as 11 October 2017. This has now been corrected in the PDF; the HTML version of the paper was correct from the time of publication.

Published online: 30 November 2017

\begin{abstract}
(c) Open Access This article is licensed under a Creative Commons Attribution 4.0 International License, which permits use, sharing, adaptation, distribution and reproduction in any medium or format, as long as you give appropriate credit to the original author(s) and the source, provide a link to the Creative Commons license, and indicate if changes were made. The images or other third party material in this article are included in the article's Creative Commons license, unless indicated otherwise in a credit line to the material. If material is not included in the article's Creative Commons license and your intended use is not permitted by statutory regulation or exceeds the permitted use, you will need to obtain permission directly from the copyright holder. To view a copy of this license, visit http://creativecommons.org/licenses/by/4.0/.
\end{abstract}

(c) The Author(s) 2017

\footnotetext{
${ }^{1}$ Committee on Immunology, University of Chicago, Chicago, IL 60637, USA. ${ }^{2}$ Department of Pathology, University of Chicago, Chicago, IL 60637, USA. ${ }^{3}$ Department of Medicine, Section of Rheumatology and Gwen Knapp Center for Lupus and Immunology Research, University of Chicago, Chicago, IL 60637, USA. Correspondence and requests for materials should be addressed to A.B. (email: abendela@bsd.uchicago.edu)
} 